\title{
CLINICAL STUDIES OF THE PSYCHIC FACTORS CONCERNED IN FUNCTIONAL PSYCHOSES.
}

BY CHARLES F. READ, M. D., Physicion in the Illinois State Psychopathic Institute, Hospital, Ill.

Of late years the study of psychiatry, having already established its right to consideration as an art, has ventured still further or in the highway of progress, and now under the notable leadership of Freud and Jung seeks some consideration as a science.

Given a patient exhibiting certain phenomena long ago labeled hallucinations, delusions, fancies or dream states, we find that we can no longer content ourselves with a bald description of these end results, even though we accept a tentative classification based upon the picture which the patient presents in his reaction to them. We must know what we can of the mental stress and strain through which the individual has traveled to the bourne of his psychosis. We must attain what knowledge we can of the especial groups of associated ideas he has acquired as a result of the conflict of his more or less primitive desires with his upbringing and environment.

These groups of ideas centering about a hope more or less realized have been quite aptly termed complexes and exist in the mental life of every one of us. When they are colored by an exceptionally vivid emotional tone, or affect, they tend to link to themselves a considerable number of ideas and thus, as it were, to form complex-constellations-whole systems of interacting hopes and fears, concretely expressed in terms of the individual's experience, and most often sexual in character.

When these so-called constellations give pain because of their lack of conventionality-when they do not fit into the general scheme of the individual's life as he must live it-they are quite often set aside or repressed, and we speak of them then as being more or less submerged. When a functional psychosis occurs, we have learned to expect often to find in its symptoms, manifestations of the activity of these powerful, though more or less subconscious factors. The autonomy of the conscious self or ego 
having become lessened, if not entirely destroyed, in its place we catch sight here and there of these other selves that will no longer be close housed. To determine the character of these desires, as well as the conditions under which their conflict with reality has taken place, is the office of psycho analysis, which term, though it has a somewhat formidable ring, in reality stands for nothing more mysterious than a patient inquiry into the mental processes of the subject under examination. To this end hypnotism, hypnoidal states and word association tests may be used, but it all comes down in the end to a matter of plodding, methodical inquiry, coupled with a close observation of the various emotional reactions that occur from time to time, and as clever discernment as possible in the interpretation of the results obtained at various stages of the inquiry.

In illustration of what I have been attempting to outline, I wish first to call your attention to the case of Miss T. F., a young woman of 28. When received she was apparently much depressed, whining and lachrymose, showing some agitation and rather a conscious air of martyrdom. Quite often she stripped off her night dress, would not remain in bed, refused to eat, and at one time even urinated on the floor. When questioned she talked quite freely in a whining monotone that somehow failed to convince one of entire sincerity. Spontaneously, she asked to be prayed for, cried quietly, said it was only when she came to know George (a young theological student) that she really cared about praying, remarked that she had to suffer, but was not willing to bear the cross, accused herself of being a liar, then of having killed "everybody," and asked to be taken away to her punishment. Questioning brought out the fact that she accused herself of being wicked toward her mother because she had struck herwhich event, however, occurred after the onset of the psychosisthat she had spent a penny against her mother's wishes when a little girl and had lost her ring, that she had made money dishonestly, had had a child that she thought of as John the Baptist, etc.

When I asked her, "Why should you be selected to be the mother of John the Baptist when you say you are so bad?" she replied, "I don't know-I have such funny thoughts-I thought of taking the stuff that comes out of me and drinking it." 
In this reply we have quite fully revealed the sexual character of the disturbance. The thought of drinking her own urine is a plain instance of reversion to childhood impressions-the interest of children in the excrements being one of the first sexual affects to be aroused.

In further search along these lines I met with less resistance than is usual in such cases, but at critical times my patient gave me very helpful signs by the shedding of tears, hesitations and exclamations such as, "Oh! I don't know," "I am so stubborn," etc.

Patient investigation revealed the fact that when a child of eight she received what was apparently her first psychic shock in the sight of the nude body of a small cousin of the opposite sex. After this she was taught onanism by another girl, practiced it once with a small boy and for some time with other girls. Upon the street at about this time she chanced to see an exhibitionist and ran home in terror. After this time she denies sexual indulgence of any kind, and I rather believe she is honest in this; but her curiosity concerning matters of sex continued to be great and to be satisfied only by listening to the talk of older girls, reading what she could in books, etc. Never did she talk of these things with anyone fit to explain them to her. When she was about 13 years of age, her mother and father separated on account of the latter's infidelity, concerning which she doubtless heard particulars at the time. When about 15 or 16 she witnessed (with another girl) the birth of some puppies, which event impressed her so strongly as to show of itself that at this time there was already a group of ideas associated by this sexual urge and possessed of a strong feeling tone.

This in the main is her early sexual history, so far as obtained, though at 19, when in college, she was still greatly interested in these matters, and states that even to talk of them with other girls greatly excited her. Thus she probably remained up to the time of her psychosis. Inasmuch, however, as she came of a religious family, belonged to the church, etc., she repressed these thoughts as desires neither compatible with her external relationships as an unmarried woman, nor with her inner relationships, that is, with the stronger desire to be moral she had acquired by education. 
At 27 she fell in love with a young theologian, not able to marry for financial reasons and but slightly interested in her, according to all accounts. In spite of this, however, she states concerning their relations: "I considered it making love-no one else seemed to think so-they tried to make me think he wasn't paying any particular attention to me. I thought of being his wife." Here in this assumption we have evidence of the beginning of her psychosis. She commences to be separated from reality by the intensity of a desire, which, born of childhood experiences, is now stimulated to renewed activity. And still how very small, as yet, is the rift-how many young women have felt these same things.

She now feels so "funny" that she asks her aunt to pray for her. This request, she believes, is overheard by her lover, and soon she feels strangely blest, knowing that he too is praying for her-which is to say, she begins to express her sexual urge in religious terms. Over the wall with which she has more or less surrounded the camp of this dear foe, the old repressions clamber, aided by the destructive effects upon that wall of the emotions now freshly aroused. The man involved has not thought of marriage, also he is a good young fellow and very possibly ignorant of the girl's perturbations. She herself is restrained by her inculcated morality from going to the bad, but not from fleeing into a psychosis for the satisfaction she now must have. Her heredity is bad; the father a ne'er-do-well, an uncle and granduncle have been insane, the mother and one cousin are said to be queer, and coupled with this there has been a faulty education. Do you wonder then at her choice?

This half-dream life is still, however, an unhappy one, because the old resistance continues, even though less powerful than heretofore. Wish fulfilments, therefore, appear more or less disguised, as distorted and transitory symbolisms. The old ego, the one aware of moral laws and anxious to abide by them, is shocked and distressed by the multitude of lewd fancies that confuse its activity. So when the resultant of the psychic trauma of childhood inflicted by the exhibitionist is reproduced in fancies concerning what she terms, "the thorn in the flesh," we are not surprised at the Biblical terminology. In this case the patient is fully aware of her subterfuge, but allows it to pass since it wears the mantle of respectability. 
She now entered upon a period of erotic excitement, mingled with a vague religious enthusiasm, and in January of this year, after some months of mental storm and stress, was sent to visit a married cousin whose husband is a minister. She states that while here she enjoyed the latter's sermons much and felt they were doing her a great deal of good. She prayed for the object of her affections, but soon found to her dismay that she was against her will harboring evil thoughts about this ministerial cousin. She remarks: "Jessie (the wife) made fun of his sermons. I don't think she is living now. I thought I had killed her in some way." Which is to say that Jessie, as the wife, stood in the way of lustful wish fulfilments concerning the husband. Jessie also disturbed her pious pose with unseemly efforts to cheer her up, whereupon the patient's more or less automatically acting complexego seized upon this fine excuse of sacrilege to do away with the one who stood in the way of its desire, while the more conscious self, though accepting this necessity in part, is still distressed and at a loss whether to place the event in the realm of fact or that of fancy.

More and more the sexual complex dominates the situation until the emotions connected with this trend of thought become quite overwhelming. The light of desire becomes stronger than that of day, and in it one fine morning while combing her hair, she suddenly sees her lover down on the street, and moreover sees him make an indecent gesture-which is to say that she experiences an objective wish fulfilment in her first hallucination or illusion. At night she feels that he comes to the house and that he prays for her. She hears him speak to her "almost as if in words." Again while driving she sees him at work upon a farm and " the Holy Spirit " moves her to go to him and make up with him-again a delightfully symbolic use of the scriptural terms. She is also troubled by sadistic thoughts concerning her cousin's small child, which shock and terrify her because she loves it. For these reasons she begins to feel more and more that she is lost, and expresses these fears in mawkish, stereotyped terms.

After a few weeeks of this she is sent home by her cousin and the next Sunday " the Spirit." moves her to go to church and to be married there to the object of her affections. Only her mother's prayers, as she states it, prevent her from. doing this. 
However, not to be cheated out of the satisfaction due them, we find her desires the same night projecting their associative interplay upon the groundwork of reality in the form of a parturition drama. In spite of the fact that she knows the physiology of sex after a fashion, she bears a child after a manner which she describes as closely resembling that of puppies, witnessed so long before; and her mother plays a part (which I will not describe) strongly suggestive of the persistence of a childish belief in the connection of onanism with childbirth. She vaguely thinks of the young man as the father of this child, and again of God as giving it to her-thus easing her moral self, her "conscience," with the thought of an immaculate conception. Moreover, she thinks of this child as John the Baptist, thus accomplishing the same purpose-this particular name being doubtless suggested by the desire her lover has expressed to became an " evangelist."

I have already described her manner on admission to the institution when her penitential attitude strongly suggested a pose and she did not show the amount of apprehension and agitation normally associated with as intense a conviction of impending punishment as she voiced. A certain monotony of speech and expression also pointed to an apparent disturbance of emotional reaction, while some confusion of ideas concerning the purpose of her punishment seemed to indicate a weakening of apperceptive activity. But why did she adopt this pose? Because, I believe, of her peculiar training and home influences. An uncle is the minister of the church in which she has been a too active worker. Her mother is a peculiar individual of rather prudish tendencies, and the object of her affection is a young divinity student. What wonder is it then that her religiously educated self feels that it must do penance for the strange events in which it finds itself willy-nilly involved, and searches out indiscriminately all the petty errors of past and present to help account for a feeling of unworthiness.

A word association test gave a very beautiful picture of an extremely complexed psyche- of a mental state colored by an emotional tone, dependent upon the sexual urge as expressed in terms of experience real and fanciful, as well as upon the above mentioned feeling of distress experienced by the morally educated self. For example, I take a reaction obtained in response to the 
word large, which was a total failure to react and denoted emotional stupidity occasioned by the strong effect aroused by the word. When asked whether the word was pleasant or unpleasant to her and to speak out whatever might come into her mind in this connection, she replied: "Not very pleasant to have the abdomen being filled up with water and everything else-I have been eating too much-a woman with a child-large house-I coughed it up-a pencil-blood-thought of tonsils being cutUncle John ran a knife into his mouth once, Jessie told me, and cut his tonsils." Here she cried and when I asked why, said: "I am scared over what is to happen to me." To this I add in explanation another reaction, that to the word "mouth" which was "out" in six seconds, a very considerable delay. "That pencil I had in school," she explained, "since being here I have thought of its coming out of my mouth, but someone would first have to put it in for me-gag me with it."

It is readily seen that the word large at once impinges upon her desire for sexual gratification, a family and a home; but in resisting a frank acknowledgment of this, she comes out with a statement quite to the opposite effect. However, she does acknowledge that she is eating too much-that is, she substitutes the confession of one carnal appetite for another. From this she proceeds (by an association wholly dependent upon the general feeling tone now aroused) to the somewhat fantastic statements concerning the pencil-blood-the running of a knife into the mouth, etc., and it is in explanation of this that I have added her later statement, that in order to have the pencil come out of her mouth it must first be put in for her. In all this we find a sexual intercourse fantasy, expressed in three different forms and in all according to the law laid down by Freud: namely, that in such dissimulation there is a transference of the pudenda from below upward, and the use of various phallic symbols. First we have the general statement, "I eat too much." Then, "Uncle John ran a knife into his mouth," and finally, "The pencil (plainly a phallic symbol) would first have to be put into my mouth."

I have reproduced here, after the manner of Jung, a diagrammatic scheme of this association test, only regretting that space forbids the explanation of its many interesting reactions. The 
list is that of Jung slightly modified. Practically all delays are the result of arousing the dominant complex. (Chart I.)

In a similar manner, after coming to the institution, she constructed the mode of her punishment, which was to be stripped of her clothing, bound and gagged and given the tube-she had been restrained in camisole and had been tube fed. Once she added to this, "and assaulted by the crazy man"-a fellow patient with whom she was brought to the institution. Note

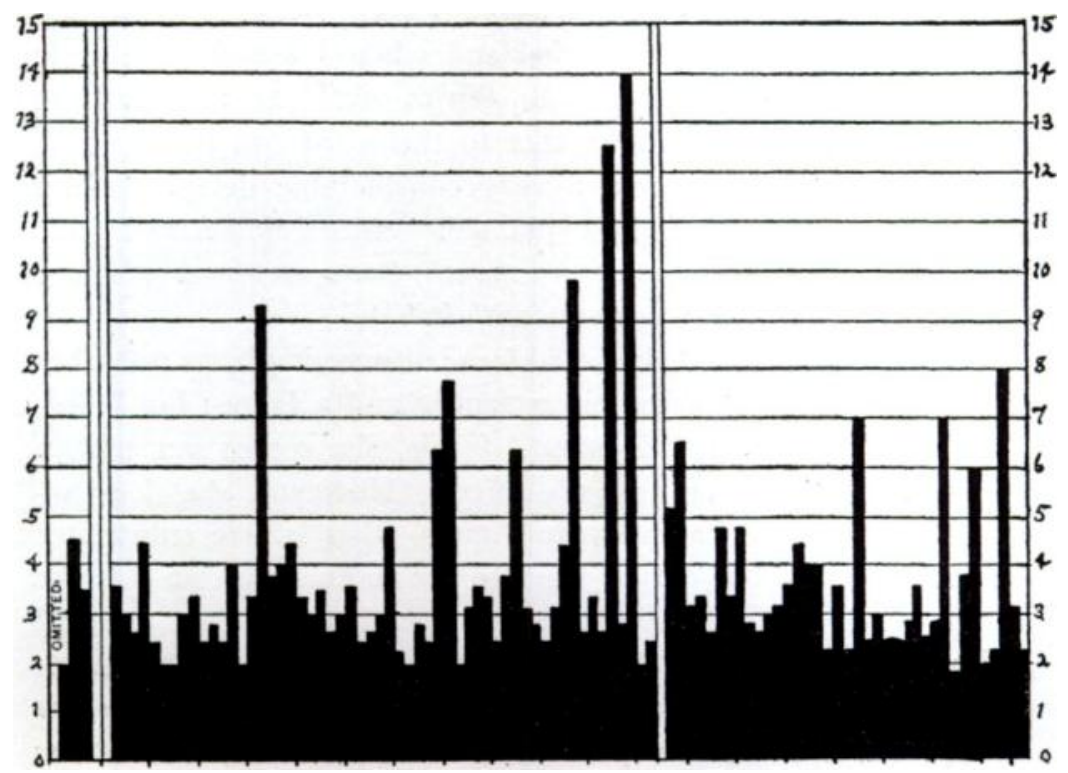

T.F. 6.2 .1910

\section{Chart I.}

again how effectively she uses the materials at hand to symbolize her repressed desire.

During this imperfect study of her case the patient gradually improved and is now in a fair way to go home. I regret that I cannot here go into her katamnesis, which is highly interesting, in that it contains a surprising recital of various dream fancies, conditioned by the most insignificant events, but all more or less moulded by the controlling constellation-complex. One only of these fancies I must mention, because it illustrates so clearly the 
influence of childhood experience upon the adult's psyche. While in a private sanitarium for a short time she fancied she saw as a man the boy with whom, when they were but eight yeaers old, she had been guilty of a childish indiscretion-only this time she felt he wished her to commit with him a far graver one. And again, a little later, while in the Detention Hospital, she thought she saw his mother and wanted to confess to her the childhood offense.

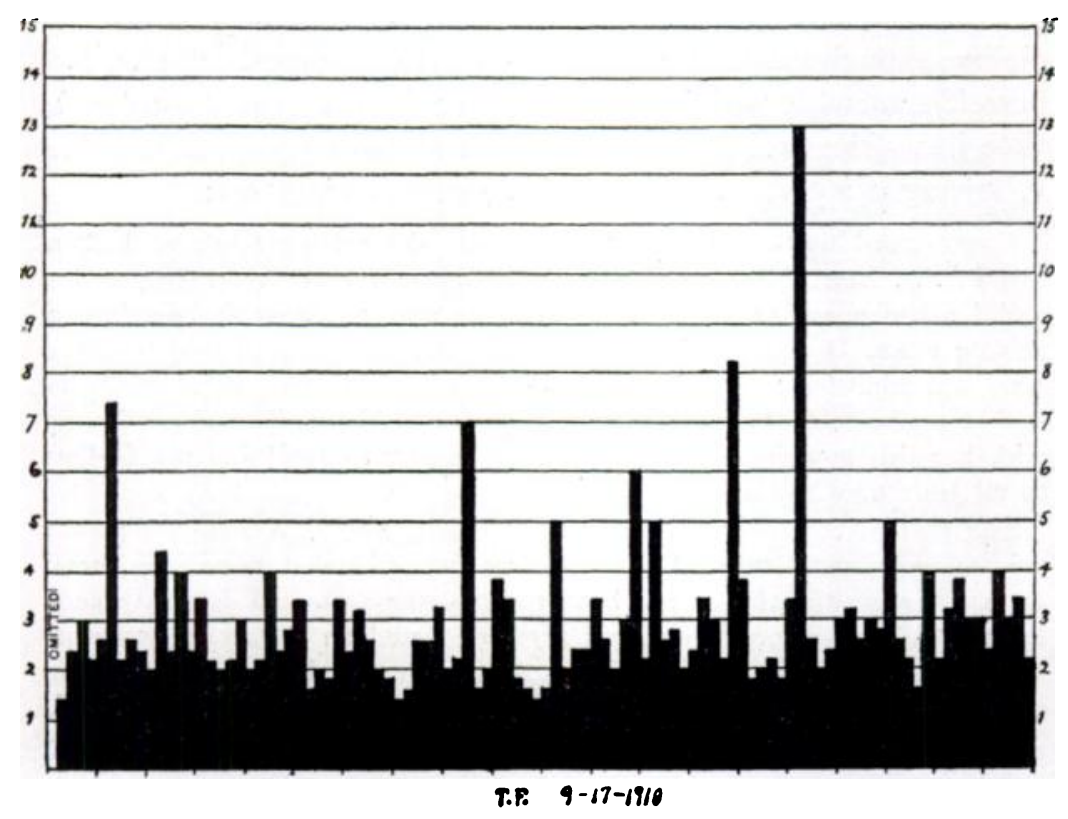

Chart II.

I add here the profile of her association test, taken three and a half months after the first one, and using the same list of words. You will note at once that she is still highly complexed, but not - so much so by far as when received. There is, as it were, a dying down of the emotional fires-an approach to the normal. (Chart II.)

Another case of similar character is that of Miss E. H., a woman of 47 , admitted a few months ago. When received she was clear and able to give an excellent account of herself, but 
filled with fancies to which she reacted quite freely. Her mood seemed adequate to the ideas in the foreground of consciousness, but varied with almost childish rapidity, so as to give one the impression of erratic irresponsibility-as if the various strange ideas which she expressed from time to time were literally " popping " into her head and were quite as foreign to the patient herself as to the physician of whom she constantly sought reassurance.

From the first she was upon the whole fairly amenable to discipline, though momentarily quite resentful at times. She busied herself somewhat with basketry and needle-work, but spent much time in writing to her mother and the attending physician. The following is a portion of one of her many productions:

Every word written to Fra Elbertus was the solemn truth as I then saw it. . . . Last night out of the everywhere a fear descended upon me and $I$ asked nurse (I'm a baby) to change my bed from the ward to a private room. I feared the Jewess beside me. Uncle Will told me they were not admitted to the Masons. May he be forgiven. What motto is it that reads, "All we are brethren; one is our Father." I shook hands with her this morning and called her my sister, as typifying my feeling to all Jews now and always.

The fear of blood-water seemed to be everywhere, pursued me to the private room, and I sneaked out, rolled up in my blanket, rested my cheek on a red rose, the top of my head touched the piano. I felt safe as I lay on the sand-colored floor and my feet rested on the steam radiator, typifying fire, the great gift of Prometheus to man. I was an old squaw and attending the snake dance with a brave; his young squaw said I could.

That snake dance is certainly the most regenerating religious ceremony it was ever my good fortune to attend. It is terrifying and humiliating, but cleansing; and it teaches one to know himself. It teaches an equal morality; that it speaks well for the women when men are faithful to their families. I think laws will soon be introduced compelling a physical examination to parties intending to marry. I also hope the snake dance will be a compulsory preparation for engaged couples. It would do away with divorce forever. I thank my friends for putting me through such a course of training. They came and I knew them not. At $3 \mathrm{a}$. $\mathrm{m}$. this morning I arose from the sand-colored floor and shortly after a loud cry rang out. I saw my sister, the Jewess. In that moment I knew I had been among those who crucified the Christ, a Jew. I was blind and now I see. Then I read the Romanist mysteries, and knew from experience that Mary ought not to be worshipped. I am a Catholic now and forever. I joined at 3632 by the sign of the Red Cross while in the bath tub. The religion of prayer is a dead and past religion. There is more real Chris- 
tianity in relieving the sick and suffering than in all the prayers ever offered. "Inasmuch as ye do it unto the least of these, ye do it to me." I am anxious to do and do now; to let the dead past bury its dead; to let what dreams can come true, by attending to the duty nearest at hand. It was a very rotten kind of Mother of Christ that I saw after I knew myself. And to think that I was frightened that I would be. (The italics are the writer's.)

Here you will observe we have to deal once more with the problem of sexual complexes, as revealed in the reference to the snake dance and to the desire for laws concerning the examination of engaged couples, etc. Again you will note that the construction is good, but the phraseology quite stilted, and that there is about it rather an obvious air of egotism. The writer is not simply recording something in which she is absorbed-she is also endeavoring to create a good impression.

In this connection it is interesting to note that a word association test shows a highly complexed, but fairly well-marked, predicate type with a tendency to use foreign equivalents and flowery elaborations-thus apple is reacted to with the judgment of Paris - family with the unit of the nation-flower with the expression of God's thought-friendly with Amicus and correct with richtig; which latter equivalents, however, are conditioned by noteworthy incidents in the patient's life. When a young teacher she tutored a favorite scholar (of whom we shall hear more presently) in Latin; and while in Germany years ago she was innocently guilty of a grave breach of correct deportment.

In women after the fortieth year, according to Jung, an increase of the predicate type takes place. This, too, he states, " is the precise time, when, owing to deficiency of sexuality, there often occurs considerable emotional loss. When a test person evinces a distinct predicate type, it may always be inferred that a marked internal emotional deficiency is thereby compensated." (Lectures American Journal of Psychology, Vol. 21, No. 2.) Especially is this true, he believes, of those who are inclined to give amplified reactions similar to some of the above.

This feature is of interest, but I shall proceed no further along this line, inasmuch as the reactions themselves did not figure in my study of the case. I give the word association schema merely in order that you may note its general similarity to those of the 
former case. The delayed reactions are again a marked feature and the majority more or less dependent upon the dominating complex-constellation. (Chart III.)

Simple inquiry was the only method employed, and the patient for the most part talked freely and with a relatively small display of serious affect, though she could by no means be said to be indifferent.

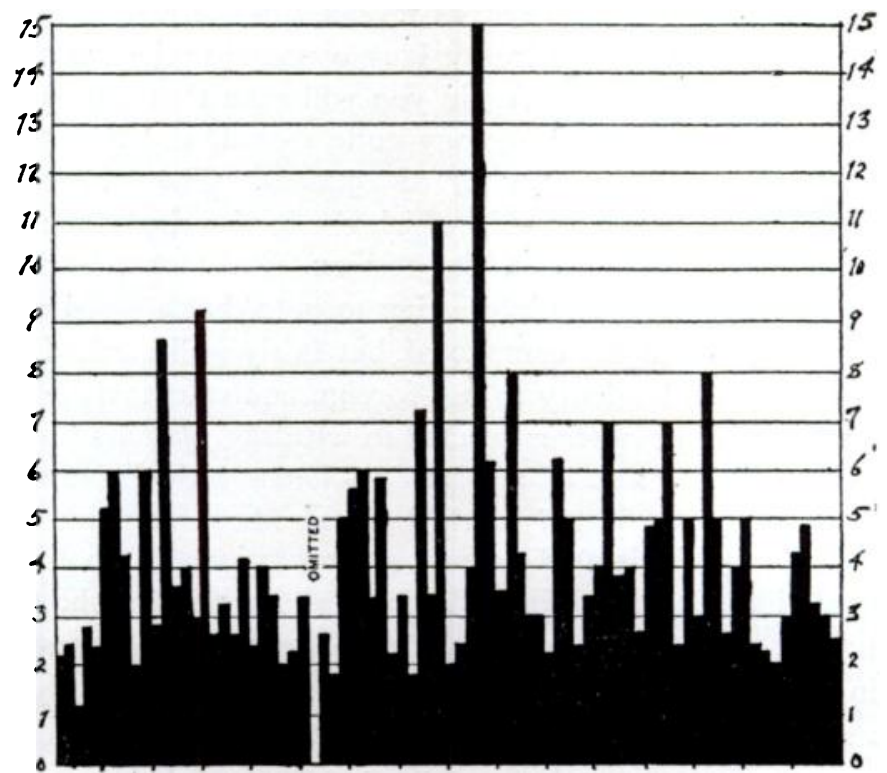

EH. $7-28-10$

Chart III.

During the first interview she replied as follows to a request for a brief account of her early life:

When mother was married she and my father owned a little home. She came up here and I was born in Chicago. She just came to her mother's on a visit. Her mother and father were born and bred in Kentucky. ... I think my father drank all his life. He was born and bred a gentleman, and only once did I ever see him act in any other way than as a gentleman, but he didn't support my mother. My Uncle Ed gave him the money and he gave it to Mamma, I think. I don't know just how it was, but any way my mother didn't know my uncle gave it to her. She thought my father furnished it. As soon as she found that out, she broke up 
housekeeping and came to Chicago to live. She had four children. . . . My Uncle Ed gave her some money-about $\$ 50$ a month, and she earned the rest until I was 16 years old. Then he said that I could go to work. My mother did not want me to be a shop girl, so she struggled along by herself. When I was between 16 and 17 we didn't have enough to eat. We went cold, too. When I was I7 I had an abscess on my inner ear which pressed against the brain-I screamed for three weeks. The doctor did not trephine. Then I had a three-years' siege with my stomach, when I lived on digested milk, not even a mouthful of water. At the end of three years I could eat ordinary food, that is, if I didn't drink coffee or things like that. I was always morbid. Had no playmates. Morbid because I could not dress and be like other children. The rest of my family were in comfortable circumstances, all branches of it. My mother never told me anything about the science. When I was 12 years old there was one month that my monthly course didn't come around. Not knowing anything more than a baby, and having heard that babies come from not being sick, I thought I was to have a baby for the punishment of my father. I had always heard that the sins of the father were visited on the children. I never knew until that month how I was to be punished. I bought poison, put it in an upper drawer. That was the third day, and then my mother saw I was so miserable and asked me what was the matter. I told her and she said nothing was the matter, that it couldn't be. Since that day I have not believed the Bible.

Note here in contrast to the letter quoted above, how clear cut is her account of a morbid, cheerless youth, and of a complex manifestation which obviously points to still earlier experience. An account of these earlier childhood traumata I obtained only after many interviews and only when I had gained her confidence enough to be able to ask that she tell me what I felt must exist.

After some considerable show of embarrassment she finally told of how, when a child of five or six, her drunken father had chased her about the room with a stick in his hand, until her mother interposed; then of how a little later, when in bed with her parents and supposedly asleep, she had overheard their conversation during intercourse-had heard her mother ask her father if this was all that he cared for her now ; had heard her father admit this and that he went with other women. Also she heard him assure her mother that she need not fear becoming pregnant.

From this time on affairs of sex, she asserts, were distasteful to her. Accompanying and following this account there occurred a most marked emotional reaction. Her rather exasperating insouciance disappeared; she cried and quite bitterly regretted 
having said anything. The same day she wrote a letter to her mother which evidenced a distinct relapse in her mental condition and the following day she gave me a note in which she related several childish offenses of a sexual character committed when four or five years old-among them, one with a small boy. "For forty years," she continued, "I have sought for purity. These things have always been a horror and a nighmare to me. I think they made me abnormal in my outlook upon life, and paved the way for the loss of my dear boy, because I was inconsiderate of my mother." (This she explains by saying that her abnormality made her thoughtless and for this she was reproved by her lover, to whom we shall come directly.)

When eleven or twelve years old and soon after puberty, she expressed the fear of becoming pregnant, as already stated, the mechanism of which is now fairly evident. As in the former case, we find the idea of an immaculate conception, but associated here with the thought of punishment for a father's sin-the nature of which had been strikingly impressed upon her childish mind; and it is very possible that in this manner she succeeded in taking her mother's place in relation to her father-the quite classical substitution in this instance being concealed by the fancy of punishment.

As a child she had few friends, resented her poverty and was inclined to be suspicious of others' motives. Between 17 and 20 she was ill, in spite of which, however, she became a teacher, though this was against her inclination, because she did not feel that a woman should work for her living. At 28 she became deeply interested in a boy of 16 , a scholar in one of her eighthgrade classes. When questioned concerning him she showed many signs of discomfiture and some resentment, but at last gave a fairly clear account of an ardent but innocent relationship existing over two years and closing with her own sojourn for nine months in a sanitarium. After a year or more of a companionship so close that he used to write her daily when he did not see her, she began to feel that the disparity of twelve years in their ages was too great, and that the affair could not go on. Her stomach began to trouble her, and the thought of sexual matters vaguely disturbed her. Then quite suddenly one night she experienced what she describes as " a slight sexual feeling," and con- 
ceived the idea that she had been assaulted and was to become a fallen woman. The following day she consulted a physician and was so completely reassured that she states she suffered no more from fears or delusions. Nevertheless, she was sent away to a sanitarium where her mother states she presented much the same delusional state as at the present time. Here, however, she seemed fully to regain her health, but before doing so, wrote to the boy a letter which led to his losing confidence in her and thus ultimately to a dissolution of their relationship.

For the next fifteen years she taught school and made a success of it, though it was always an effort for her and she did not enjoy it. She was still subject to spells of anger, elation and depression. At 37 a sudden menopause established itself without untoward symptoms. Two years later she heard of her youthful lover's marriage, which apparently affected her but little at the time. The following year, however, she suddenly quit teachingupon a leave of absence-to study art for a few terms. She was boarding at this time because her mother had broken up the home, owing to her sister's poor health.

At 42 she permanently stops teaching and goes to live with a wealthly uncle, but is soon forced out of his home by a vulgar woman he has married, goes to another city to study art upon a meager stipend allowed her by another aunt, only to become convinced there that the pupils and teachers do not treat her properly. As a result she becomes "utterly desperate," is taken back to Chicago by her mother, secures lodgings-because there is no room for her in the home where her insane sister is being cared for-and again begins to study art. For a year she makes good progress, then does less well, and at last becomes troubled again by the realization that here, too, everyone is against her.

A pathetic picture is it not? That of a homeless, disappointed, sexless woman, filled with vain memories and repressed desires, casting aside her life work and means of livelihood at the call of an urge she does not understand, to sally forth upon the field of art in quest of inner peace and satisfaction-a petticoated Don Quixote, equipped with brush and pallet in place of sword and buckler.

Next she learns that a long expected legacy has failed to materialize, and in January of this year we are not at all surprised 
to find her again developing a psychosis-and a psychosis shaped by the sexual complex originating in childhood traumata, and given definite shape 20 years ago by the repressed desires associated with the blighted romance of teacher and scholar. Remember, too, that a sister is insane; two cousins have suffered a psychosis, also an uncle; and the father died a drunkard by violence.

Here, again, can we wonder that a constellation-complex a second time gains the upper hand, to manifest itself once more in an impression of assault that drives her from her room at three o'clock in the morning, leads her to believe that she is being hypnotised, and that she is to become a fallen woman to serve as a vicarious sacrifice for all those of the "red-light" district? (She has been interested in a revivalist's parade through the levee.) The shades of old desires, the forms of expiring hopes battle with the weakened censor of the conscious self for a belated existence of their own, and in a few days drive her to the home of the man she has loved as a boy, there to secure gratification in a semi-symbolic manner, which she relates as follows:

There was a former pupil of mine (at this time the examiner knew nothing concerning their relationship) who had asked me to call on his wife-during this time that I was not myself at all I called on his wife. I imagined it was Sunday afternoon-I thought it was the red-light district-a man and his wife came in-I thought this man was a hypnotistI thought he finished by hypnotising me, what my brother-in-law had begun. (This brother-in-law, she explains, had been talking to her concerning a theosophical belief in "spiritual conception.") I was the same there. I couldn't talk-I couldn't. I was delirious-I think I actually saw this. I want you to know my exact condition. Then he took up my fur-lined coat when I said I must go and held it for me, and I imagined there and then that I conceived. Then I went to my aunt's, who called in a doctor. $I$ thought they wanted me to be the mother of the next Christ. I wanted to be just a woman. I seemed to go through the sickness that a woman goes through. I was awfully sick and they sent me to Penoyer. (The italics are mine.)

We have here an exceedingly graphic account of a state of emotional stupidity in the presence of a reaction to subconscious impulses; the grossness of which reaction is somewhat veiled with the seemingly hastily borrowed mantle of a theory of immaculate conception. Remember, however, that 35 years before this, the 
nucleus of this same constellation accomplished its manifestations in a similar form. To be the mother of Christ is but one corollary of this assumption-similar to the thought of John the Baptist in the preceeding case. When I asked her how she thought she could become the mother of Christ in the levee district she replied: “ . . . it seemed as though I was hypnotised and people were making me believe one thing and then another to confuse me so that I couldn't control my actions. I would forget to eatdidn't clean my teeth for weeks." Note again the similarity to the other patient's reply when asked a like question. Again it is a matter of "funny thoughts"--thoughts that are not recognized by the conscious self as its lawful associates.

A little later grandiose ideas appear in the fancy that she is to be trained by means of some vague " code" to become a diplomat -in which fancy no doubt an ambition complex finds voice, conditioned by the fact that she has always considered her life as not fitted to her birth, also by the fact that a noted diplomat now dead was a distant cousin, and many of her family have been prominent judges, lawyers, etc.

For several months she remained at the sanitarium, the subject of varying fancies, at times suspicious, but never really apprehensive. Upon her return to the city, however, in June of this year, she became again "terribly nervous," felt as impelled by some force, fancied again that she was to be made a bad woman, and was greatly troubled over something she describes as "yellow, sticky stuff" (in reality varnish) that got upon her hands, and which she interpreted as a sign to the public of her loose character. When finally asked point blank as to its symbolism (quite late in the course of my study and after many of her inspirations had been explained to her) she promptly responded that it was a sign of assault and referred its origin back to an experience with a masseur, who a month or two before this had shown her some vaginal applicators-in what she took to be a very suggestive manner-after which he gave her local massage and in withdrawing the applicators left something upon the labia that produced blisters, which for a time made her very anxious about possible infection. Here, again, we find the dominating complex, making use of the material at hand to build in extreme detail the structure of a sexual intercourse fantasy. 
True hallucinatory experience can scarcely be said to exist, though when troubled by the fancy of pregnancy, she hears a voice one night say: "To-night a human soul is born"; and several months later she sees the form of what she takes to be an aunt long dead-an aunt noted for her purity and rectitude of thought and life.

Another acute attack of fear reacted to by screaming and violence finally led to her being taken to the Detention Hospital, where she again fancied herself assaulted and in a resort. It is here, perhaps, that we find her most exquisite example of automatonism. When asked to write her age, she is certain that she wrote 46 , but at the instant felt a momentary shock pass over her and after a short turn about the room, returned to find upon the ledger page the figures 34 , which she believes they must have substituted there while her eyes were turned away. Twelve years, you will remember, measure the disparity in ages, upon which rock the ship of her happiness foundered twenty years ago. Also the year before this, the boy grown older and influential, had spoken of his age as 34 when she called upon him to perform for her some little act of courtesy. Other phrases of his conversation at that time she now repeats, believing that they are a part of some code. Moreover, she selects from a bouquet of carnations sent her in the Detention Hospital, a single white flower, places this alone in a white vase and carries it about until she chances to see a male attendant or interne eyeing her strangely, when suddenly the words "and is that all you care about me?" come to her, whereupon she promptly drops the vase, flower and all in terror and disgust.

Years before this the school boy had told her he would keep her "safe-locked in the strong tower of his heart," and to her now the carnation symbolizes her own pure self, kept unsullied in the vase which represents the tower of her lover's heart. She is aware of the symbolism but enjoys the make-believe until the glance of the man recalls the old repugnance, when straightway she lets the matter drop-thus reacting symbolically in the same manner as she did in real life twenty years before. The words which come to her are those of her mother on the night of the childhood experience already described. 
Her conduct since admission to this institution I have already outlined. The communication quoted in the beginning is quite characteristic of her present mental state, but unfortunately is too long to be explained in detail. It is, as she expresses it, the transcription of sentences such as constantly come into her mind as if spoken-in fact she has referred to these thoughts as "voices," though she explains that they are in the brain, not outside, and believes they may be due to some species of mental suggestion undertaken by her friends and the doctors. All are more or less disjointed fragments of the subconscious associative activity which constitutes the semi-automatically acting complexego.

The patient at present is quite nervous; is reacting so thoroughly to the interviews of the past few days as to make her condition one of partial relapse. Explanatory therapy thus far is entirely without result, but I still hope for the future.

In conclusion, the writer has only to say that he trusts these cases as presented may have given concrete form in some degree to the introductory statement. Many, indeed, are familiar with these classical deductions in connection with border-line cases, but possibly not so many have chanced to become interested in their application to the actual psychoses. Even if one adhere to some particular belief concerning the physical basis of this or that socalled functional insanity, there still remains much for him to do in determining the psychic factors in the case. If one cannot bring himself to believe that psychic stress and strain actually cause the psychosis, he still must grant that they condition its manifestations. 